Mills, S.W. (2009) Bringing the Family Tradition in Bluegrass Music to the Music Classroom. General Music Today,22(2): 12-18. (Winter 2009) Published by Sage (ISSN: 1931-3756).

\title{
Bringing the Family Tradition in Bluegrass Music to the Music Classroom
}

Susan W. Mills

\begin{abstract}
National Standard 9, "understanding music in relation to history and culture," forms the basis for this article about family traditions found in bluegrass music. With historical information about the roots of bluegrass music in the Old Time tradition, the author provides helpful links and instructional strategies to help general music students identify important components and concepts found in bluegrass music. The Digital Library of Appalachia is introduced to provide sound archives available to all teachers, and a sample lesson plan is included. Also included is a suggested listening repertoire, along with recommendations for use in the general music classroom.
\end{abstract}


National standards for music and arts education specify that music students should engage in activities that help them understand music in relation to history and culture (Consortium of National Arts Education Associations, 1994, Standard 9). Music reading and performance skills are often developed successfully in many public school choral and instrumental programs for particular individuals. In the folk music and folk art traditions, historical information and cultural expression are often preserved through family traditions in noneducational settings. Family traditions include learning music from relatives at informal gatherings and singing with family members to create three- and four-part harmony.

Passing along the music from one generation to the next has been a mainstay of folk music and the preservation of art forms that define traditional cultures found in immigrant-based communities, rural areas, and the recognized heritage areas and corridors throughout the United States. The U.S. Department of the Interior (n.d.) designates heritage areas, sometimes called corridors, "where natural, cultural, historic, and recreational resources combine to form a cohesive, nationally-distinctive landscape arising from patterns of human activity shaped by geography" (para. 1). Geography figures prominently in regional music traditions, and the context of these traditions includes geographical origins, family ties, and common musical elements.

In-depth study and performance of at least one musical style outside that of classic art music training has been suggested in music education literature as an effective method of preparing future music educators to address cultural and historical understanding (Campbell, 2004; Richardson, 2004). For many current music educators, such study and performance may not have occurred during the college years, and the celebration of American diversity in a general music curriculum may sound exciting yet also overwhelming at the start. Such a celebration should include lesson plans and repertoire appropriate for general music students as well as a cultural context for the music. The art of celebrating the diverse American folk traditions is tying it all together in the classroom, which can be accomplished by taking a closer look at the context from which these rich genres of music grew.

\section{CULTURAL CONTEXT: GEOGRAPHY AND THE FAMILY TRADITION}

Using the cultural context of the Kentucky heartland and Southern Appalachia, family tradition as a theme, and a focus on National Standard 9 in performance practice, students can learn about the development of country and bluegrass music prior to its commercialization through the present time. Several other standards are well addressed in the teaching suggestions (see Appendixes A and B).

"Daddy sang bass, Mama sang tenor, me and little brother would join right in there...." This song from the album Johnny Cash: 16 Biggest Hits holds a clue about the cultural path and the geography of bluegrass music. The lead singer on that song is Johnny Cash (now known as the wayward country musician in the hit movie Walk the Line), who was married to June Carter, a member of the famous Carter family of musicians from Southern Appalachia. During his childhood in the 1930s, the popular sound of gospel quartets swept the southern United States. 


\section{Figure 1}

\section{Bill Monroe}

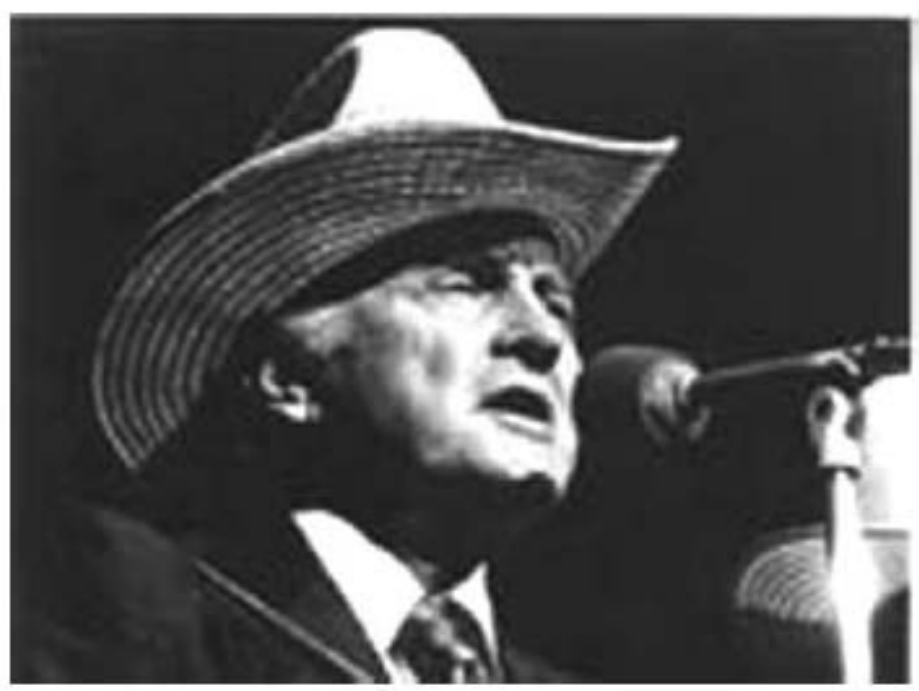

Source: Courtesy of Southern Appalachian Archives, Berea College, Kentucky. Reproduced with permission.

Although the days of the singing schools and masters who taught people to sing via shape notes had come to a close, many people in the Appalachian region greatly enjoyed gathering for harmony singing. Songbook publishers often sent out quartets to promote new music that would be available for these eager part singers. Throughout the South, formation of gospel singing quartets became a model imitated in rural homes by parents and their children. The families' varied vocal timbres made for part assignments, so Daddy could sing bass, and Mama could sing tenor!

The Carter family members, famous for their contributions to country music, were part of an Appalachian family who joined together in song, like so many families. Their path, however, led them to eventual fame. A. P. Carter, his wife Sarah, and his sister-in-law Maybelle sang and played many traditional songs in the early 20th century that country and bluegrass musicians are still performing. They began recording music in 1927 and are credited with the first recorded versions of many standard Old Time, country, and bluegrass songs (Papa \& Mogford, 1990). A. P. Carter collected songs for recordings during the 1930s with the help of guitarist Lesley "Esley" Riddle, an African American musician who influenced Maybelle's guitar style, which later came to be known as the Carter "scratch" (Papa \& Mogford, 1990). Many of their songs are appropriate for children and easy to find in music textbooks and songbooks, such as "The Wabash Cannonball" and "Keep on the Sunny Side." Students can also view an educational video about the Carter family's musical journey and significant contributions to the development of American music at www.pbs.org/wgbh/amex/carterfamily (PBS Online, 2005). The five segments are approximately 1.5 minutes in length. 
Also in 1927, Bill Monroe, a Kentucky musician, created bluegrass music (Figure 1). His upbringing and love for music was truly a family tradition. He and his brothers created an entire new music genre in bluegrass. Later, a multimillion dollar industry of performing and recording grew during the 20th century (Rosenburg \& Wolfe, 2007).

\section{THE BLUEGRASS SOUND}

In the 19th century, many Appalachian people came through North Carolina to the Appalachian Mountains of Kentucky, and many left for the North and Midwest, looking for work and carrying little in the way of material possessions. In the mountains of Eastern Kentucky, "bluegrass" referred to the flatlands between the Appalachian ridges and the western border of the state. The songs and instruments remembered and played were precious cultural treasures. The instruments formed the basis for the signature sounds of bluegrass music, directly descended harmonically and sometimes physically from Scottish and Irish instruments such as bagpipes and fiddles (Smith, 2000). The complete bluegrass instrument family is made up the fiddle, banjo, guitar, mandolin, string bass, dobro (an acoustic guitar with a metal resonator built into its body), autoharp, and vocal harmonies resembling that of White gospel music (see Figure 2).

\section{Figure 2}

\section{Bluegrass Instruments}

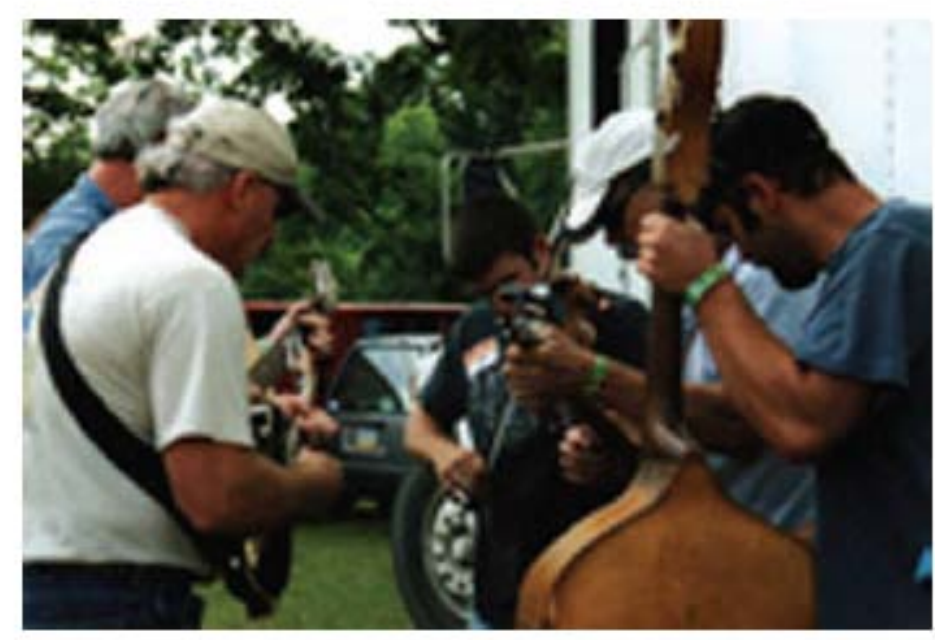

Source: Courtesy of Southern Appalachian Archives, Berea College, Kentucky. Reproduced with permission. 
In the early 20th century, the banjo was a jazz instrument imported into American music from Africa, and still today bluegrass music continues to include many jazz qualities, especially the art of improvisation. Contemporary musicians who recreate earlier American folk banjo music play in the "Old Time" tradition of banjo picking, known as "claw hammer." To the experienced listener of bluegrass and Old Time banjo music, the difference between the two playing styles is quite distinctive. In addition to the claw hammer, it is helpful to think of Old Time music as a body of repertoire based on an Appalachian, family-oriented lifestyle. Bluegrass, on the other hand, can be thought of as an outgrowth of the Old Time tradition that developed along more commercial lines of preservation and performance (Wilson \& Ferris, 1989, p. 994).

Figure 3

A Mandolin

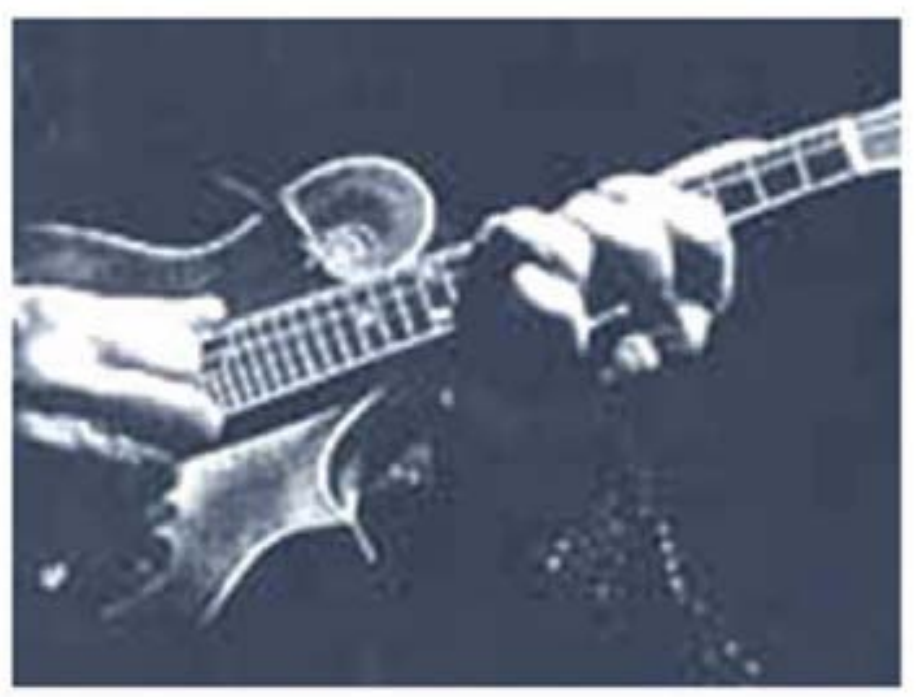

Source: Courtesy of Southern Appalachian Archives, Berea College, Kentucky. Reproduced with permission.

Monroe, a mandolinist (Figure 3), fused the influences of his two childhood mentors, Pendleton "Uncle Pen" Vandiver and African American country blues player Arnold Schultz (Smith, 2000). Vandiver's fiddle-playing techniques became an intricate part of Monroe's style of mandolin playing, and Schultz inspired Monroe to spice his mandolin playing with blue notes and blues licks (Smith, 2000). The mandolin's blues influence combined with the part singing of the Monroe brothers became known as the "bluegrass" sound. This early fusion created a unique and unmistakable style that was cutting edge for the 1930s. Monroe changed the name of the band to the Bluegrass Boys, claiming the title and enjoying great commercial success. 
Many well-known bluegrass musicians such as Earl Scruggs and Ralph Stanley developed their bluegrass sound by playing as members of Monroe's Bluegrass Boys at one time or another (Mills, 2007). Eventually, the bluegrass sound spread beyond the boundaries of Appalachia and became a popular niche in the musical recording industry.

The Carters, the Monroes, and most early bluegrass musicians were familiar with shape-note singing, and later four-part gospel singing, as a way of harmonizing melodies. These close harmonies and religious themes are still common in bluegrass music, although the music has become part of popular culture and enjoys great commercial success as a separate music industry. It is important to recognize the influence of African American musicians on both of these legendary families. Although such influences are often omitted or unknown to students, they are vital links in the chain of the American folk music tradition.

Figure 4

The McLain Family

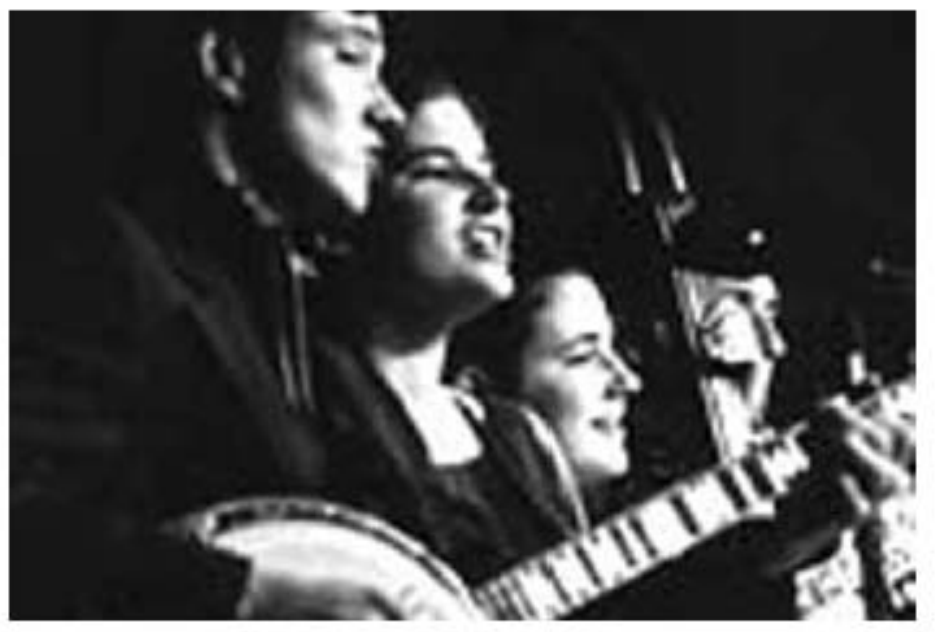

Source: Courtesy of Southern Appalachian Archives, Berea College, Kentucky. Reproduced with permission.

The Digital Library of Appalachia (DLA; Appalachian College Association Central Library, 2007) is a collection of digitized sound recordings of Appalachian music, stories, and photographic artifacts related to the culture of the southern and central Appalachian region. The contents of the DLA are drawn from special collections of Appalachian College Association member libraries. You can visit the Web site at www.aca-dla.org and download the excerpts and, in some cases, full-length recordings for educational use. The "Advanced Search" feature allows searching any title as an "Exact Phrase," which makes finding the items very easy. The teaching suggestions listed in the appendixes utilize musical recordings found in the DLA. Although the difference between the Old Time and bluegrass music selections may be mere nuances to the 
ears of very young students, the exploration of American folk music from the Old Time through bluegrass traditions can be a successful path to student understanding of music as it relates to history and culture. Understanding can be based on (a) the family tradition as a lifestyle, (b) the cultural context of the mountain and rural geographical region, and (c) the performance practices and sounds of legendary bluegrass and Old Time musicians, past and present.

\section{PERFORMANCE PRACTICE}

Part of the real fun in bluegrass performance practice is the improvisation and solo or lead breaks taken by the various performers during a song. Not associated with the Old Time practice of all musicians playing the melody or rhythm together, the lead breaks stand out as a bluegrass treat for listeners. Entire pieces intended for one or more featured instruments (usually banjo) are called breakdowns. (You may be familiar with the famous "Foggy Mountain Breakdown," by Lester Flat and Earl Scruggs, as it is widely recognized as a banjo breakdown.) As a start for understanding breakdowns, students can listen to "Raymond's Breakdown," by the McLain Family Band, using the DLA to establish the sound of the solo bluegrass banjo. The McLain Family Band (Figure 4) recorded the Concerto for Bluegrass Band and Orchestra with the Carleton College Orchestra (Rhodes, 2004). Movement I, titled "Breakdown," begins with an arrangement of the Old Time song "Cripple Creek," played as a banjo breakdown followed by a four-part sung chorus. This concerto, composed by Phillip Rhodes, features the bluegrass band and the orchestra as separate but cojoined entities in a fascinating three-movement work that is quite enjoyable and serves as a great example of the versatility of a musical style that may deceptively appear narrow. Using guided listening, however, students will learn that the music can feature breakdowns, blues voicings, gospel harmonies, and a range of lyrical content from Old Time repertoire to newly created works.

From the DLA collection, examples of breakdowns, three- and four-part harmony singing, featured improvisational solos, Old Time claw hammer picking, and songs from both the Old Time and bluegrass genres provide the music needed for accurate and interesting general music lessons.

\section{TEACHING SUGGESTIONS}

Encouraging students to listen to unfamiliar music is always challenging, but with movement, singing, and instrument play, students can be engaged and interested in traditional folk music and contemporary versions of the traditional styles. The learning and performance tradition in bluegrass music is aural, meaning that written notation is not important and need not be included in lessons about bluegrass music or its roots in Old Time music. Comparing many versions of songs is simple and fun if you have the recordings to play. Through comparative listening, students can hear the Old Time versions of songs and tunes, and then find common or differing elements and playing styles in modern versions. Much bluegrass repertoire is taken from Old Time songs and arranged on the spot in live performances or in more organized 
versions in recorded arrangements. A list of suggested tunes for comparison is included in Appendix C.

Using iTunes, music teachers can audition 30-second samples of thousands of songs and instrumental works. These samples are free to download and use in the classroom, as permitted by Apple, Inc. (2007). In addition, many Web sites provide similar opportunities to hear excerpts, which are often long enough for classroom use. Most of the time, there is an option to purchase the individual selection for as little as 99 cents. The Smithsonian Global Sound Collection includes a collection of folk music from the Appalachian tradition as well as cultural traditions from around the world (Smithsonian Institution, 2007). In addition to using music from the DLA, photos of musicians can be captured for classroom use with the "Images" feature of Google, the Smithsonian Global Collection site, and the iTunes site. If you have a computer with speakers loud enough for students to hear and a stable, high-speed Internet connection, you have many sound and photographic resources literally at your fingertips.

\section{REFERENCES}

Appalachian College Association Central Library. (2007). Digital library of Appalachia. Available from http://www.aca-dla.org

Apple.com. (2007). iTunes. Available from http://www.apple.com/ itunes

Campbell, P. (2004). Teaching music globally. New York: Oxford University Press.

Cash, J. (Vocalist). (1999). Daddy sang bass [Album version]. On Johnny Cash: 16 Biggest Hits [CD]. New York: Sony.

Consortium of National Arts Education Associations. (1994). The national standards for arts education. Reston, VA: MENC.

Mills, S. (2007). Appalachian music fellowship final report. Berea, KY: Southern Appalachian Archives, Special Collections and Archives, Berea College.

Papa, J. (Writer), \& Mogford, G. (Director). (1990). Mother Maybelle's "Carter Scratch" [Video recording]. Santa Monica, CA: Mebcon Production.

PBS Online. (2005). The Carter family: Will the circle be unbroken. Available from http://www.pbs.org/wgbh/amex/carterfamily

Rhodes, P. (Composer). (2004). In performance at Carleton (1975-2003): Phillip Rhodes, Composer. Northfield, MN: Bachrach Studios.

Richardson, C. (2004). Multimusical competency for music educators: Problems and possibilities. College Music Symposium, 44, 68-73.

Rosenburg, N., \& Wolfe, C. (2007). The music of Bill Monroe. Urbana: University of Illinois Press. 
Smith, R. (2000). Can't you hear me callin': The life of Bill Monroe. Boston: Little, Brown.

Smithsonian Institution. (2007). Smithsonian global sound. Available from

http://www.smithsonianglobalsound.org

U.S. Department of the Interior. (n.d.). What is a National Heritage Area? Retrieved from http://www.nps.gov/history/heritageareas/FAQ/INDEX.HTM

Wilson, C., \& Ferris, W. (Eds.). (1989). The encyclopedia of southern culture. Chapel Hill: University of North Carolina Press.

\section{Appendix A Standards-Based Ideas for Bluegrass Music Lessons Standard 6: Listening to, Analyzing, and Describing Music}

Describe in simple terms how musical elements are used in music examples from various world cultures.

- Students can participate in description via listing with the class on a worksheet or in a written journal.

Demonstrate perceptual skills by answering questions about and describing aural examples of music representing diverse cultures.

- Students can listen and compare versions of the same tunes and songs such as those in the list of suggestions (Appendix C).

\section{Standard 9: Understanding Music in Relation to History and Culture}

Compare, in several cultures of the world, the functions that music serves, roles of musicians, and conditions under which music is typically performed.

- Students can reenact gatherings where group singing and instrument play take place.

- Students can discuss the idea of being a cultural ambassador through music. 


\section{Appendix B Sample Lesson for Grades 4-5 National Standard 6: Listening to, Analyzing, and Describing Music Objectives}

- Use appropriate terminology in explaining music, musical instruments and voices, and musical performances.

- Identify visually and aurally a variety of instruments including many orchestra and band instruments and instruments from various cultures.

- Identify solo and group vocal timbres including children's voices and male/female adult voices.

\section{Resources}

- Internet access

- Photos and recordings in the Digital Library of Appalachia (DLA): www.aca-dla.org

- Bluegrass instruments, if available

\section{Procedures}

1. Discuss bluegrass music with students and where we might hear it. View photos of various bluegrass musicians/ family bands from the DLA. Discuss the various settings (festivals, concerts, homes) of the performances and the recording sessions.

2. Invite students to join in a Big Set, which is a dance from Kentucky. Each student needs a partner. Practice and dance the Big Set to the music of the McLain Family's "Bill Cheatham" from the DLA, using the following movements (or create your own variations).

- Form a circle with all students, and lead students in circling left, then right.

- Right-hand swing with partner, then left-hand swing.

- Promenade around the circle clockwise, and begin the dance again at the teacher's discretion.

Acting as the dance caller, the teacher cues changes in direction and new figures at the ends of musical phrases. Although the exact number of steps is not established in the Big Set tradition, a suggested number of beats would be the following:

- Circle: 16 or 32 beats

- Swing: 8 or 16 beats

- Promenade: 16 or 32 beats 
In the correct promenade and circle formation for Kentucky style Big Set, boys stand to the left of girls, if they are paired boy-girl, though it is not necessary for the essence of this lesson.

- 3. Ask students to identify the music that they heard. Tell students that this family of musicians includes singers and instrumentalists playing traditional bluegrass instruments. Introduce the bluegrass band and family of instruments, including the fiddle, banjo, guitar, bass fiddle, and mandolin.

- 4. Play the following excerpts of recorded songs from the DLA and help students identify the instrument with the sound. List each instrument on the board, with factual information or photo and remarks made by students describing each instrumental timbre.

"Pretty Polly," by the McLain Family Band, banjo and four-part harmony vocal "Chicken Reel," by Jim and Bill Fuller, mandolin "Blackberry Blossom Reel," by Bob Simmons, fiddle "Arkansas Traveler," by Lewis and Donna Lamb, fiddle and guitar "Back Up and Push," by the McLain Family Band, bass (solo vocal, three-part vocal) and fiddle

- 5. Review information about Bill Monroe, known as the "Father of Bluegrass," focusing on the instruments in his band.

- $\quad$ 6. Teach the refrain and practice with autoharp or guitar; then lead students in singing with the recording.

"Will the Circle Be Unbroken" (Traditional)

Refrain

Will the circle be unbroken?

By and by, Lord, by and by,

There's a better home a-waitin'

In the sky, Lord, in the sky.

\section{Closure}

Play the following selections from the DLA archives and ask students if they think the music should be called bluegrass or if it should be called Old Time and why they chose that style. Ask what they heard in the music to help them decide. Students' answers may disagree with the styles listed below, but their justification for answers should contain correct identification of instruments heard in each excerpt.

"Blue Moon of Kentucky," by Bill Monroe: bluegrass

"Don't Let Your Deal Go Down," by Kinney Rorrer: Old Time 
"Deep River Blues," by Doc Watson: Old Time

"Back Up and Push," by the McLain Family Band: bluegrass

"Old Joe Clark," by the Barnes Family with Lewis

and Donna Lamb: Old Time

\section{Evaluation}

- Look for use of musical terminology in student description, such as harmony, rhythm, and melody.

- Look for recognition of musical instruments in the listening selections.

- Look for identification of children's voices (students), solo vocals, and part singing in the discussion of vocal timbres in Step 5 and in closure.

\section{Appendix C Suggestions for Comparative Listening}

"The Fox," by Nickel Creeka (Nickel Creek, 2000, Warner Bros.), available from iTunes

"The Fox," by Pete Seeger (American Favorite Ballads, Vol. 2, 2003, Smithson Folkways), available from Smithsonian Global Sound

"Pretty Polly," by the McLain Family Band (live performance), available from the Digital Library of Appalachia (DLA)

"Pretty Polly," by Lillie Mae Ledford (live performance), available from the DLA

"Old Joe Clark," by the Barnes Family with Lewis and Donna Lamb (live performance), available from the DLA

"Old Joe Clark," by Spud Gravely (live performance), available from the DLA

"Will the Circle Be Unbroken," by Janette Carter (live performance), available from the DLA

"Will the Circle Be Unbroken," by the Nitty Gritty Dirt Band (Will the Circle Be Unbroken, Vol. 2, 1989, Universal Music Group), available from iTunes

"Some Dark Holler," by Dwight Yokum (Dwight's Used Records, 2004, Koch Records), available from iTunes

"Dark Hollow Blues," by Bill Monroe (live performance), available from the DLA

"Orange Blossom Special," by Lewis and Donna Lamb (live performance), available from the DLA 
"Orange Blossom Special," by Mark O'Connor (The New Nashville Cats, 1991, Warner Bros.), available from iTunes

a. A link to Nickel Creek, a contemporary bluegrass band, is available at www.youtube.com/watch?v=7|2U2U\&nMtl\&feature=related.

Before Bill Monroe developed bluegrass music, people sang and played some of the same songs, but they didn't use the mandolin. There was either no banjo or a different kind of banjo. This style of music is now called "Old Time."

The Carter family began traveling and recording their Old Time music in 1927, about the same time that Bill Monroe and his bluegrass band, "The Bluegrass Boys," were traveling, recording, and becoming known for the bluegrass sound. Note that Old Time songs were accompanied with the autoharp and guitar when played by the Carter family. Like bluegrass music, Old Time music is still being played today although it is sometimes difficult to tell the two styles apart.

"Will the Circle Be Unbroken" is one of the Carter family's most famous Old Time songs. It tells about the importance of the family in their religious faith, now and even in heaven "at the throne." 